\title{
Alternative grafts for brachioaxillary hemodialysis access: 1-year comparative results
}

\author{
Opções de enxerto para fístula bráquio-axilar: \\ resultados comparativos em um ano de seguimento \\ Sergio Quilici Belczak ${ }^{1,2}$, Sergio Ricardo Abrão 3 , Vinicius Bertoldi ${ }^{4}$, Thiago José Cavaquini², \\ Luiz Felipe Mansano Slavo ${ }^{2}$, Igor Rafael Sincos 2,5 , Ricardo Aun ${ }^{3}$
}

\begin{abstract}
Background: Many chronic renal patients lack autologous veins in the upper limbs suitable for construction of arteriovenous fistulas for hemodialysis. Alternative fistula options for these patients should be evaluated and compared. Objective: To compare different types of grafts used for brachioaxillary access in hemodialysis patients in terms of their patency and complication rates. Method: Forty-nine patients free from arterial system abnormalities and with no venous options for creation of arteriovenous fistulae in the arm and/or forearm underwent brachioaxillary bypass with implantation of autologous saphenous vein, polytetrafluoroethylene (PTFE), or PROPATEN ${ }^{\circledR}$ grafts. Patients were assessed by Doppler ultrasonography at 3, 6, and 12 months after surgery,. Results: The four first saphenous vein grafts had failed by 3 or 6 months after surgery. The autologous saphenous vein group was discontinued at the beginning of the study because of extreme difficulty in achieving puncture and hematoma formation. Failure rates of PTFE and PROPATEN ${ }^{\circledR}$ grafts did not differ after $3(p=0.559), 6(p=0.920)$, or 12 months $(p=0.514)$. A log-rank test applied to cumulative survival of grafts at 1 year ( 0.69 for PTFE, 0.79 for PROPATEN $\left.{ }^{\circledR}\right)$ detected no significant differences $(p=0.938)$. There were no differences in complications resulting in graft failure between the two types of prosthetic graft. Conclusion: Autologous saphenous vein grafts do not appear to be a good option for brachioaxillary hemodialysis access because of difficulties with achieving puncture. Brachioaxillary fistulae constructed using PTFE or PROPATEN ${ }^{\circledR}$ grafts exhibited similar patency and complication rates. Further studies with large samples size are warranted to confirm our findings.
\end{abstract}

Keywords: arteriovenous fistula; renal dialysis; saphenous vein; polytetrafluoroethylene; heparin/administration \& dosage.

\begin{abstract}
Resumo
Contexto: Há inúmeros pacientes renais crônicos sem veias autólogas nos membros superiores para confecção de fístulas arteriovenosas para realização de hemodiálise. As opções de fístula nestes pacientes devem ser avaliadas e comparadas. Objetivo: Comparar diferentes enxertos para acesso braquioaxilar em pacientes hemodialíticos, em relação a permeabilidade e taxas de complicação. Método: Um grupo de 49 pacientes, sem alterações no sistema arterial e sem opções venosas para criação de fístula arteriovenosa no braço e/ou antebraço, foi submetido a procedimentos cirúrgicos para implante de diferentes enxertos: veia safena autóloga, enxertos de PTFE e PROPATEN ${ }^{\circledR}$. Resultados: Os quatro primeiros implantes de veia safena falharam no terceiro e no sexto mês após a cirurgia. Interrompeu-se o uso de veia safena autóloga no início do estudo pela extrema dificuldade de punção e pela formação de hematoma. Não houve diferenças nas taxas de falha dos enxertos de PTFE e PROPATEN ${ }^{\bullet}$ após três $(p=0,559)$, seis $(p=0,920)$ e 12 meses $(p=0,514)$ de seguimento. $O$ teste de Logrank aplicado à sobrevida cumulativa dos enxertos por um ano $\left(0,68\right.$ para PTFE; 0,79 para PROPATEN $\left.{ }^{\bullet}\right)$ não relevou diferenças $(p=0,938)$. Não foram encontradas diferenças entre os enxertos prostéticos em relação ao tipo de complicação que determinou as falhas. Conclusão: $O$ enxerto de veia safena autóloga parece não ser é uma boa opção para acesso braquioaxilar em hemodialíticos, já que implica em dificuldade na punção. Os enxertos de PTFE e PROPATEN ${ }^{\circledR}$ em fistula braquioaxilar resultaram em permeabilidade e taxas de complicações similares. Estudos com amostras maiores são necessários para confirmar nossos achados.
\end{abstract}

Palavras-chave: Fístula arteriovenosa; diálise renal; veia safena; politetrafluoretileno; heparina/administração e dosagem.

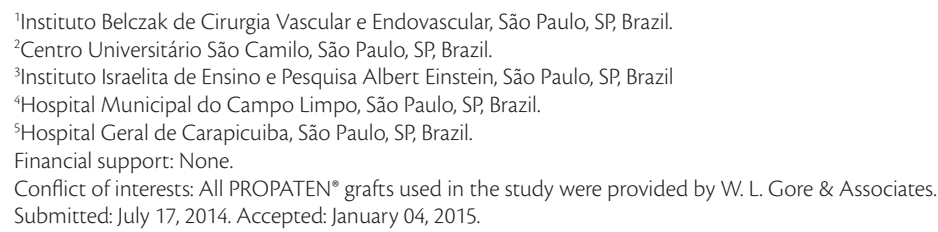




\section{INTRODUCTION}

An increasing number of patients with chronic kidney disease depend on hemodialysis and maintenance of functional vascular access is a determining factor of successful hemodialysis. ${ }^{1}$ Optimal access with an autologous arteriovenous fistula (AVF) offers a safe approach to the patient, provides appropriate flow for hemodialysis, is associated with low rates of complications and mortality, and involves lower costs. ${ }^{1,2}$ The first-choice access for upper limbs is a radiocephalic AVF, because these are easily constructed and have been associated with few complications, while brachiocephalic AVFs and other autologous veins are good secondary choices. ${ }^{3}$

However, in many patients it is impossible to use upper-limb autologous veins for several reasons, including individual abnormalities of arteriovenous anatomy, failure of previous transposition fistulae, ${ }^{4}$ degenerative processes resulting from the underlying disease, excessive previous punctures of these veins, ${ }^{2}$ and atherosclerotic processes inherent to diabetes ${ }^{5}$ or advanced age. ${ }^{6}$ Alternative techniques using central venous catheters have been developed for situations in which autologous AVF is impossible. However, in addition to the very high costs involved in maintaining these types of access, they are also associated with high rates of complications, resulting in frequent hospital admissions and additional morbidity among patients with chronic kidney disease who require hemodialysis. ${ }^{2,3}$

Other alternative techniques include biological or prosthetic grafts. Both saphenous vein $(\mathrm{SV})^{7}$ and expanded polytetrafluoroethylene (PTFE) ${ }^{8}$ grafts were proposed as options during the 1970s and exhibited good short-term results in terms of patency. However, both were associated with important complications (infection, thrombosis, seroma formation, aneurysm, and arterial ischemia) and not infrequent occlusions caused by thrombosis and/or myointimal hyperplasia, leading to excessive morbidity and elevated costs.

Since 2006, it has been proposed that using heparin-bonded PTFE grafts (PROPATEN ${ }^{\circledR}$ ) could reduce the incidence rates of early thrombosis and late myointimal hyperplasia. ${ }^{9}$ Comparative studies have already shown that such grafts offer higher patency rates in lower limbs, when compared to standard PTFE grafts. ${ }^{10}$ However, the primary patency of heparin-bonded PTFE grafts in lower limbs was still inferior to the primary patency achieved with autologous SV grafts. ${ }^{11}$

There is little data in the literature documenting the outcomes of brachioaxillary AVF using PROPATEN ${ }^{\circledR}$ (recently approved for use in humans) and SV grafts (in use for more than four decades). Moreover, no studies were found in the literature reviewed that compared patency and complication rates across brachioaxillary AVFs created with expanded PTFE, heparin-bonded PTFE or autologous SV grafts.

As such, the objective of this investigation was to compare patency and complication rates of brachioaxillary AVFs created using each of these three alternative types of graft.

\section{MATERIALS AND METHODS}

After approval was granted by the Research Ethics Committee at Carapicuíba General Hospital (CEP 018/12) this study was conducted at the hospital's Vascular Surgery department. All patients were provided with explanation of the study objectives and the procedures involved and all gave their consent to participation in the study.

Forty-nine patients ( 26 men and 23 women; mean age, 57 years) who had exhausted all autologous vein options for AVF in the arm or forearm (as confirmed by previous Doppler ultrasonography) were included in the study. Patients were excluded if arterial system abnormalities were present.

Between November 2011 and July 2013, patients consecutively underwent surgical procedures to create brachioaxillary AVFs and were distributed into one of three groups: PTFE, PROPATEN ${ }^{\circledR}$ or autologous SV grafts.

All patients had surgery under local anesthesia with $2 \%$ Xylocaine and sedation with midazolam, as necessary. Initially, one incision was made at the elbow fold and another in the axillary fossa for dissection and control of the brachial artery and the axillary vein, respectively (Figure 1). Grafts were anastomosed end-to-side to the brachial artery and axillary vein using polypropylene continuous suture (Figure 2). Patients received systemic anticoagulation with $80 \mathrm{IU} / \mathrm{kg}$ non-fractioned heparin and antibiotic prophylaxis with cefazolin, $1 \mathrm{~g} / \mathrm{kg}$.

The saphenous vein was harvested at the thigh, with two longitudinal incisions and local anesthesia.

Patients were discharged from hospital on the same day as the surgical procedure, and returned to the outpatients clinic after 7 days for the first assessment. Hemodialysis was started six weeks after AVF creation for all patients. Monthly follow-up assessments were conducted to assess outcomes and need for intervention at clinical consultations. Control Doppler ultrasonography was conducted at 3,6 , and 12 months after surgery to assess patency of 
grafts and to verify occurrence of events determining failure of the procedure.

The success and failure rates observed for procedures using each type of graft were expressed as frequencies, as were complication rates observed over 12-month follow-up, and then compared using the chi-square or Fisher test, depending on the sizes of subsamples. Graft patency (survival) rates were analyzed using Kaplan-Meier product estimation and compared with the log-rank test.

\section{RESULTS}

Three of the first four cases in which autologous SV grafts were used exhibited graft occlusion at the assessment 3 months after surgery and the fourth exhibited occlusion at 6 months after surgery. The use of autologous SV was discontinued at the beginning of the study because of the extreme difficulty in achieving puncture, with consequent hematoma.

One of the 23 PTFE graft patients and two of the 22 PROPATEN ${ }^{\circledR}$ graft patients were lost to follow-up (censored).

At the end of 12-months follow-up, overall patency rates for PTFE (15/22: 68.2\%) and PROPATEN ${ }^{\circledR}(16 / 20: 80.0 \%)$ grafts were similar (chi-square $=1.60 ; \mathrm{p}=0.205$ ).

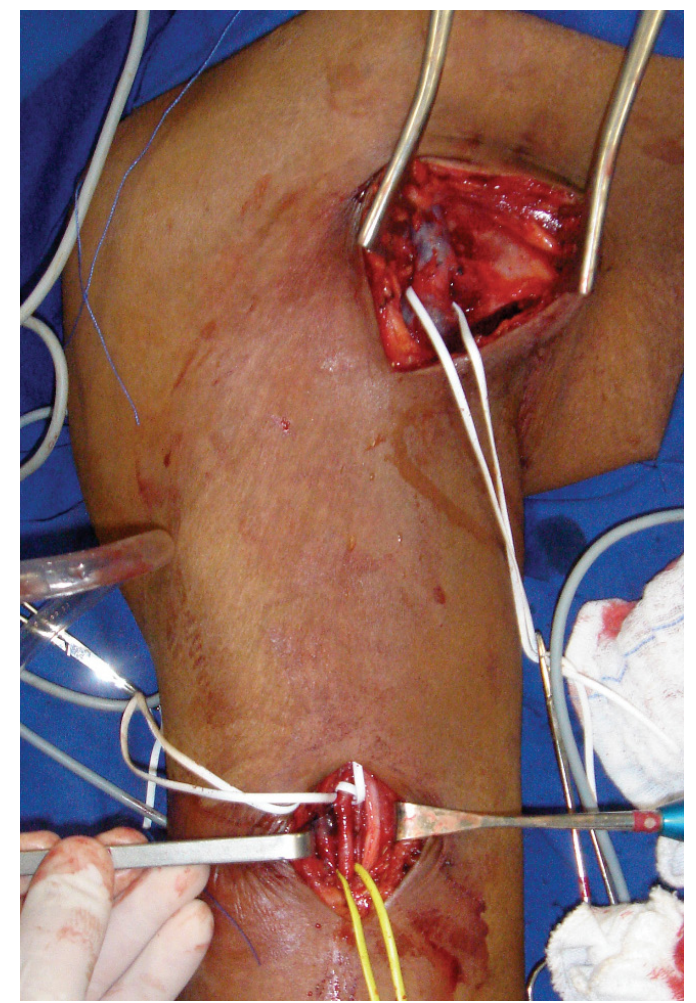

Figure 1. Dissection and control of the brachial artery and the axillary vein.
No differences were detected in success and failure rates when the three follow-up points (3, 6 and 12 months) were analyzed separately (Table 1). Curves representing failure rates during the study illustrated similar behavior; failure rates were higher for PTFE grafts at 3 and 6 months after surgery, but were very close to rates for PROPATEN ${ }^{\circledR}$ grafts at the end of the study (Figure 3). Likewise, the frequencies of complications resulting in the failure of the graft were similar $($ chi-square $=1.24 ; \mathrm{p}=0.537$ ) for PTFE and PROPATEN ${ }^{\circledR}$ (infection: $50.0 \%$ and $25.0 \%$, respectively; occlusion: $50.0 \%$ and $25.0 \%$, respectively). Puncture pseudoaneurysm was only observed in one of the patients with AVFs created using PROPATEN ${ }^{\circledR}$ grafts.

Table 2 lists cumulative survival (patency) rates (with standard errors) for PTFE and PROPATEN ${ }^{\circledR}$ grafts estimated using Kaplan-Meier products. A graphical

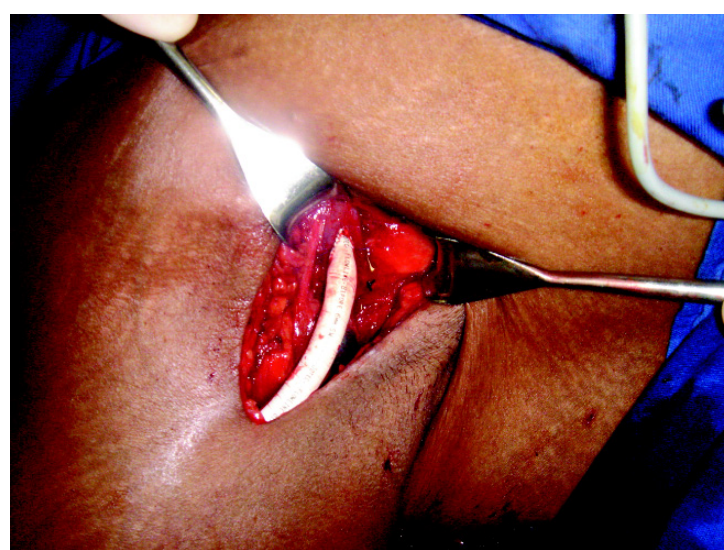

Figure 2. Grafts were bound to the brachial artery and axillary vein using $119 \times 90 \mathrm{~mm}$ prolene end-to-side sutures $(300 \times 300 \mathrm{DPI})$.

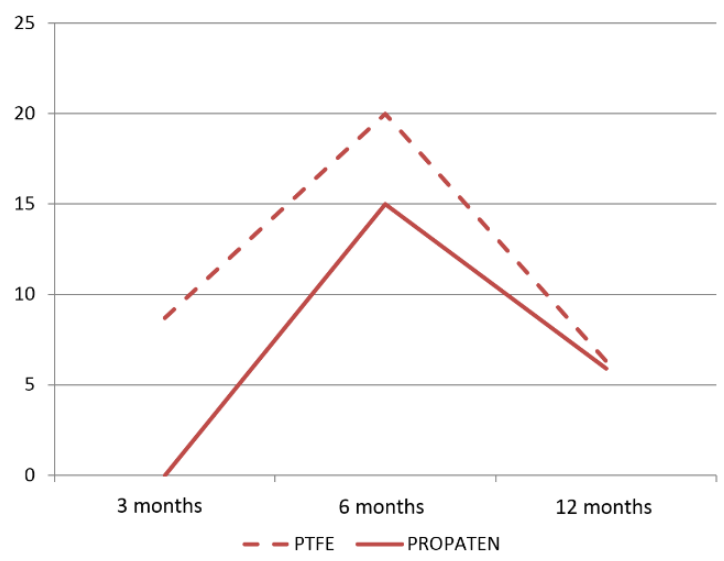

Figure 3. Graphical representation of failure rates in hemodialysis brachioaxillary fistulae created with PTFE and PROPATEN ${ }^{\circledR}$ grafts at three post-operative assessments (3, 6, and 12 months). 
representation of the cumulative survival curves can be observed in Figure 4. A log-rank test did not detect differences between survival (patency) rates (chi-square $=-0.006 ; p=0.938$ ), although there was an odds ratio of 1.72 for longer survival over the long term in favor of the PROPATEN ${ }^{\circledR}$ grafts.

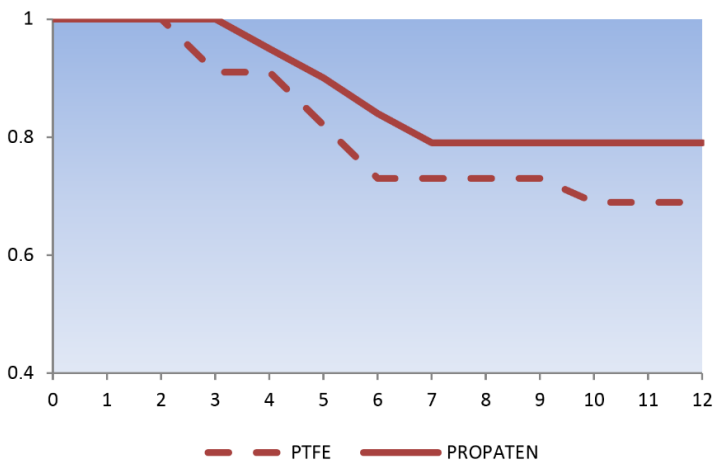

Figure 4. Graphical representation of the cumulative survival (patency) curves for PTFE and PROPATEN ${ }^{\bullet}$ grafts in hemodialysis brachioaxillary fistula over 1-year follow-up.

\section{DISCUSSION}

Radiocephalic AVF is the best vascular access option in upper limbs for successful maintenance of chronic hemodialysis. However, because of several factors inherent to the patient, the underlying disease, or even because of venous or arterial deterioration due to continued use of radiocephalic AVFs or other autologous AVFs, brachioaxillary AVFs with biological or prosthetic grafts have become more and more necessary in clinical practice. Inverted SV is the first choice among biological graft options, and prosthetic grafts should be reserved for cases in which using the $\mathrm{SV}$ is not possible. ${ }^{12}$

Ramacciotti et al. ${ }^{12}$ described the results of brachioaxillary AVF with inverted SV grafts in nine patients and compared them with results for 10 patients who received PTFE grafts. The SV grafts exhibited better patency rates and lower complication rates and infection was only observed with PTFE grafts. However, the authors stated that using inverted SV

Table 1. Frequencies of success and failure of PTFE and PROPATEN ${ }^{\circledR}$ grafts in hemodialysis brachioaxillary fistulae at three post-operative assessments (3, 6, and 12 months).

\begin{tabular}{ccccccc}
\hline Assessments & & PFTE & \multicolumn{3}{c}{ PROPATEN } \\
\hline \multirow{3}{*}{3 months } & & $\mathbf{n}$ & $\%$ & $\mathbf{n}$ & $\%$ & \\
& Success & 21 & 91.3 & 22 & 100.0 & \\
& Failure & 2 & 8.7 & 0 & 0 & $\mathrm{p}=0.559$ \\
& Total & 23 & 100.0 & 22 & 100.0 & \\
\multirow{3}{*}{6 months } & Success & 16 & 80.0 & 17 & 85.0 & \\
& Failure & 4 & 20.0 & 3 & 15.0 & $\mathrm{p}=0.920$ \\
& Total & 20 & 100.0 & 20 & 100.0 & \\
& Success & 15 & 93.7 & 16 & 94.1 & \\
& Failure & 1 & 6.3 & 1 & 5.9 & $\mathrm{p}=0.514$ \\
& Total & 16 & 100.0 & 17 & 100.0 & \\
\hline
\end{tabular}

Table 2. Kaplan-Meier estimated cumulative survival (with standard-errors) of PTFE and PROPATEN ${ }^{\circledR}$ grafts for brachioaxillary hemodialysis fistulae over 1-year follow-up.

\begin{tabular}{|c|c|c|c|c|c|c|c|c|}
\hline \multicolumn{9}{|c|}{ KAPLAN-MEIER PRODUCT } \\
\hline \multicolumn{9}{|c|}{ PTFE } \\
\hline $\begin{array}{c}\text { Time } \\
\text { (months) }\end{array}$ & $\mathbf{N}$ & Losses & Failure & Survival & $\begin{array}{c}\text { Cumulative } \\
\text { survival }\end{array}$ & & & $\begin{array}{c}\text { Standard } \\
\text { error }\end{array}$ \\
\hline 3 & 23 & 2 & 0.09 & 0.91 & 0.91 & 0.0041 & 0.0580 & 0.114 \\
\hline 5 & 20 & 2 & 0.10 & 0.90 & 0.82 & 0.0096 & 0.0800 & 0.157 \\
\hline 6 & 18 & 2 & 0.11 & 0.89 & 0.73 & 0.0124 & 0.0810 & 0.159 \\
\hline 12 & 16 & 1 & 0.06 & 0.94 & 0.69 & 0.0165 & 0.0886 & 0.173 \\
\hline \multicolumn{9}{|c|}{ PROPATEN } \\
\hline $\begin{array}{c}\text { Time } \\
\text { (months) }\end{array}$ & $\mathbf{N}$ & Losses & Failure & Survival & $\begin{array}{c}\text { Cumulative } \\
\text { survival }\end{array}$ & & & $\begin{array}{c}\text { Standard } \\
\text { error }\end{array}$ \\
\hline 3 & 22 & 0 & 0.000 & 1.00 & 1.00 & 0.0000 & 0.0000 & 0.000 \\
\hline 4 & 20 & 1 & 0.050 & 0.95 & 0.95 & 0.0026 & 0.0484 & 0.094 \\
\hline 5 & 19 & 1 & 0.050 & 0.95 & 0.90 & 0.0055 & 0.0660 & 0.129 \\
\hline 6 & 18 & 1 & 0.060 & 0.94 & 0.84 & 0.0087 & 0.0780 & 0.153 \\
\hline 7 & 17 & 1 & 0.060 & 0.94 & 0.79 & 0.0123 & 0.0870 & 0.170 \\
\hline
\end{tabular}


involves greater technical difficulty, notwithstanding the good short-term and long-term results and the absence of infection. Schneider et al. ${ }^{13}$ described 309 cases of AVF created using a variety of different donor arteries and receptor veins in upper limbs with conserved SV grafts, showing that primary and secondary patency rates were similar to those reported in the literature on prosthetic grafts. In a group of 70 patients whose AVF involved different sites in upper limbs and employed conserved SV or prosthetic grafts (Gore-Tex), Mousavi et al. ${ }^{14}$ observed no differences in functional criteria, patency rates, or occurrence of thrombosis, but they did report a significantly higher frequency of infection in patients treated with prosthetic grafts.

We were not able to compare SV grafts with the other two alternative grafts for brachioaxillary AVFs, because the autologous graft technique was abandoned at the beginning of the study in response to extremely difficult and problematic puncture in such procedures. Of the four SV grafts that were created, three cases suffered hematoma followed by occlusion before the 3 -month assessment, while the forth graft occluded 5 months after the procedure.

Previous studies have shown that use of PTFE grafts is associated with better results in brachioaxillary AVFs than in brachiocephalic AVFs, in terms of the arteriovenous hemodynamic changes resulting from placement of such grafts. ${ }^{4}$ One-year patency rates of PTFE grafts in brachioaxillary AVFs vary from 64\% to $76 \%,{ }^{5,6,9}$ but can decrease to $36 \%$ in radiocephalic, brachiocephalic, and brachiobasilic AVFs, especially in diabetic patients. ${ }^{15}$

There are also reports that patency rates of heparin-bonded PTFE grafts can be similar to those observed with autologous veins. ${ }^{16,17}$ In a preliminary, non-randomized study involving a variety of AVFs created with PROPATEN ${ }^{\circledR}$ grafts, most of them in upper limbs (66\%), the 1-year patency rate was $78 \% .{ }^{9}$

Our findings on patency rates for both PTFE and PROPATEN ${ }^{\circledR}$ grafts $(69.0 \%$ and $79.0 \%$, respectively) are compatible with those reported in the literature for 1-year follow-up.

Although other authors have reported higher patency rates for procedures with PROPATEN ${ }^{\circledR}$, suggesting an improvement of $20 \%$ in the patency of such grafts compared with standard PTFE at 1-year follow-up, ${ }^{9}$ we found no statistically significant difference (chi-square $=-0.006 ; p=0.938$ ) between patency rates for PTFE and PROPATEN ${ }^{\circledR}$ grafts. On the other hand, the odds ratio estimated for longer survival of the PROPATEN ${ }^{\circledR}$ grafts over longer follow-up was 1.72 , but this finding requires verification by future studies focusing on longer-term results.
Considering the three evaluations ( 3,6 , and 12 months after surgery) separately, the frequencies of failure were statistically similar for both grafts (Table 1), although the rate was higher for PTFE grafts at 3 and 6 months (Figure 3). Goldin et al. ${ }^{18}$ also observed similar short-term failure rates (3 months' follow-up) for PTFE and PROPATEN ${ }^{\circledR}$ grafts used to create AVFs in upper limbs for hemodialysis.

There is strong evidence showing that heparin-bonded PTFE is associated with better 1-year patency of femoro-femoral and femoro-popliteal bypasses for lower limb critical ischemia. ${ }^{10}$ However, it seems that this evidence should not be considered applicable to brachioaxillary AVFs in patients with chronic kidney disease.

Once more, we found no differences in rates of complications resulting in failure of the procedure. Just one puncture-related pseudoaneurysm was documented, for a PROPATEN ${ }^{\circledR}$ graft. Infection and occlusion rates were $50 \%$ in the PTFE and $25 \%$ in the PROPATEN ${ }^{\circledR}$ group. Goldin et al. ${ }^{18}$ reported complication rates of $10 \%$ and $20 \%$ for PTFE and PROPATEN ${ }^{\circledR}$ respectively, but these rates were from a preliminary study with just 3 months' follow-up.

It is well known that infection is significantly less frequent (2\%-3\%) in AVFs created using autologous veins, while PTFE grafts are associated with complication rates of $11 \%$ to $35 \%$ in hemodialysis AVFs. ${ }^{19}$ It is worth noting that arteriovenous graft infections can result from several risk factors. In hemodialysis patients, an immunological state involving impaired neutrophils, renal dysfunction with uremia and continued use of the AVF, providing potential access for bacteria, are all important risk factors for graft infection. Obesity, diabetes, hyperalbuminemia, and inadequate personal hygiene are also risk factors for infection. ${ }^{18} \mathrm{We}$ did not consider such factors in our study because its focus was on graft patency and complications causing procedure failure. Most published studies on PROPATEN ${ }^{\circledR}$ grafts investigate graft patency in lower limbs, ${ }^{10,16,17}$ and complication rates for upper limb AVFs have seldom been reported.

Moreover, systematic follow-up of the patients included in this sample is ongoing and will probably reveal additional findings over the long term.

\section{CONCLUSIONS}

Our findings allow us to suggest that the patency and complication rates of PTFE and PROPATEN ${ }^{\circledR}$ grafts used for brachioaxillary AVFs do not differ. In view of the complications observed in our study, we suggest that use of SV for AVFs should be 
discouraged. Further studies with larger samples size are warranted to confirm our findings.

\section{ACKNOWLEDGEMENT}

We would like to thank W. L. Gore \& Associates for providing all PROPATEN® grafts used in our study.

\section{REFERENCES}

1. Karamanidou C, Clatworthy J, Weinman J, Horne R. A systematic review of the prevalence and determinants of nonadherence to phosphate binding medication in patients with end-stage renal disease. BMC Nephrol. 2008;9(1):2. http://dx.doi.org/10.1186/14712369-9-2. PMid:18237373.

2. Centofanti G, Fujii EY, Cavalcante RN, et al. An experience of vascular access for hemodialysis in Brazil. Int Arch Med. 2011;4(1):16. http:// dx.doi.org/10.1186/1755-7682-4-16. PMid:21569616.

3. Jennings WC, Taubman KE. Alternative autogenous arteriovenous hemodialysis access options. Semin Vasc Surg. 2011;24(2):72-81. http://dx.doi.org/10.1053/j.semvascsurg.2011.05.009. PMid:21889094.

4. Karakayali H, Yagmurdur MC, Tutar NU, Basaran O, Haberal $M$. Comparison of hemodynamic changes associated with two different polytetraflouroethylene arteriovenous fistulae in hemodialysis patients. Transplant Proc. 2004;36(9):2603-6. http:// dx.doi.org/10.1016/j.transproceed.2004.09.028. PMid:15621100.

5. Ravari H, Kazemzade GH, Modaghegh MH, Khashayar P. Patency rate and complications of polytetrafluoroethylene grafts compared with polyurethane grafts for hemodialysis access. Ups J Med Sci. 2010;115(4):245-8. http://dx.doi.org/10.3109/03009731003678562. PMid:20218943.

6. Staramos DN, Lazarides MK, Tzilalis VD, Ekonomou CS, Simopoulos CE, Dayantas JN. Patency of autologous and prosthetic arteriovenous fistulas in elderly patients. Eur J Surg. 2000;166(10):777-81. http:// dx.doi.org/10.1080/110241500447407. PMid:11071164.

7. May J, Tiller D, Johnson J, Stewart J, Sheil AG. Saphenous-vein arteriovenous fistula in regular dialysis treatment. N Engl J Med. 1969;280(14):770. http://dx.doi.org/10.1056/NEJM196904032801409. PMid:5773358.

8. Tellis VA, Kohlberg WI, Bhat DJ, Driscoll B, Veith FJ. Expanded polytetrafluoroethylene graft fistula for chronic hemodialysis. Ann Surg. 1979;189(1):101-5. http://dx.doi.org/10.1097/00000658197901000-00019. PMid:758853.

9. Davidson I, Hackerman C, Kapadia A, Minhajuddib A. Heparin bonded hemodialysis e-PTFE grafts result in 20\% clot free survival benefit. J Vasc Access. 2009;10(3):153-6. PMid:19670166.

10. Lindholt JS, Gottschalksen B, Johannesen N, et al. The Scandinavian Propaten $\left({ }^{\circ}\right)$ trial - 1-year patency of PTFE vascular prostheses with heparin-bonded luminal surfaces compared to ordinary pure PTFE vascular prostheses - a randomised clinical controlled multi-centre trial. Eur J Vasc Endovasc Surg. 2011;41(5):668-73. http://dx.doi.org/10.1016/j.ejvs.2011.01.021. PMid:21376643.

11. Dorigo W, Pulli R, Castelli P, et al. A multicenter comparison between autologous saphenous vein and heparin-bonded expanded polytetrafluoroethylene (ePTFE) graft in the treatment of critical limb ischemia in diabetics. J Vasc Surg. 2011;54(5):1332-8. http:// dx.doi.org/10.1016/j.jvs.2011.05.046. PMid:21840151.

12. Ramacciotti E, Correa JA, Galego SJ, et al. Implantes arteriovenosos como alternativa para o acesso à hemodiálise. Cir Vasc Angiol. 1998;15:91-4.
13. Schneider M, Barrou B, Cluzel P, Hamani A, Bitker MO, Richard F. Value of preserved saphenous vein graft for the creation of access ports in hemodialyzed patients: report of 309 cases. Prog Urol. 2003;13(4):585-91.

14. Mousavi SR, Moatamedi MR, Me Akbari M. Comparing frozen saphenous vein with Gore-tex in vascular access for chronic hemodialysis. Hemodial Int. 2011;15(4):559-62. http://dx.doi. org/10.1111/j.1542-4758.2011.00578.x. PMid:22111826.

15. Modarai B, Dasgupta P, Taylor J, Koffman G, Khan MS. Follow-up of polytetrafluoroethylene arteriovenous fistulae for haemodialysis. Int J Clin Pract. 2005;59(9):1005-7. http://dx.doi.org/10.1111/j.1742 1241.2005.00577.x. PMid:16115172.

16. Peeters P, Verbist J, Deloose K, Bosiers M. Results with heparin bonded polytetrafluoroethylene grafts for femorodistal bypasses. J Cardiovasc Surg (Torino). 2006;47(4):407-13. PMid:16953160.

17. Bosiers M, Deloose K, Verbist J, et al. Heparin-bonded expanded polytetrafluoroethylene vascular graft for femoropopliteal and femorocrural bypass grafting: 1-year results. J Vasc Surg. 2006;43(2):313-8. http://dx.doi.org/10.1016/j.jvs.2005.10.037. PMid: 16476607 .

18. Goldin I, Shemesh D, Zaghal I, Berelowitz D, Olsha O. Evaluation of $6 \mathrm{~mm}$ heparin-bonded vascular graft versus standard graft in prosthetic arteriovenous access: first clinical results. J Vasc Access. 2007;8:201.

19. Bachleda P, Utikal P, Kalinova L, et al. Infectious complications of arteriovenous ePTFE grafts for hemodialysis. Biomed Pap Med Fac Univ Palacky Olomouc Czech Repub. 2010;154(1):13-9. http:// dx.doi.org/10.5507/bp.2010.005. PMid:20445706

Correspondence Sergio Quilici Belczak Rua Cônego Eugênio Leite, 1126/153 CEP 05414-001 - São Paulo (SP), Brazil Tel.: +55 (11) 983837803 E-mail:belczak@gmail.com

Author information

SQB - PhD at Instituto Belczak de Cirurgia Vascular e Endovascular São Paulo, SP, Brazil; and professor of Vascular Surgery at Centro Universitário São Camilo.

SRA - MD at the Vascular Surgery Unit, Instituto Israelita de Ensino e Pesquisa Albert Einstein

VB - MD at the Vascular and Endovascular Surgery Unit, Hospital Municipal do Campo Limpo, São Paulo.

TJC and LFMS - Medical students at Centro Universitário São Camilo, Vascular Surgery. IRS - PhD and head of the Vascular Surgery Unit at Hospital Geral de Carapicuiba and Hospital São Camilo; and professor of Vascular Surgery at Centro Universitário São Camilo.

RA - PhD and an MD at the Vascular Surgery Unit, Instituto Israelita de Ensino e Pesquisa Albert Einstein; and associate professor at Universidade de São Paulo (USP)

Author contributions Conception and design: SQB, RA Analysis and interpretation: SQB, LFS, TJC

Data collection: IRS, VB Writing the article: SQB, SRA Critical revision of the article: SQB, RA Final approval of the article*: SQB, SRA, VB, TJC, LFS, IRS, RA Statistical analysis: SQB, SRA, VB, TJC, LFS, IRS, RA Overall responsibility: SQB, RA

${ }^{*}$ All authors have read and approved of the final version of the article submitted to I Vasc Bras. 